\title{
APLIKASI NILAI-NILAI LUHUR PENCAK SILAT SARANA MEMBENTUK MORALITAS BANGSA
}

\author{
Moh. Nur Kholis \\ Program Studi Pendidikan Jasmani, Kesehatan, dan Rekreasi \\ Fakultas Keguruan dan IImu Pendidikan \\ Universitas Nusantara PGRI Kediri \\ Email : nurkholis88@unpkediri.ac.id
}

\begin{abstract}
Abstrak
Krisis moral yang melanda Indonesia diduga menimbulkan krisi social, ekonomi budaya, politik dan hukum, hal ini melanda semua lapisan masyarakat. Krisis moral juga menyebabkan munculnya krisi kepercayaan masyarakat pada pemerintah. Yang lebih parah krisis moral berdampak pada dekadensi moral para generasi penerus bangsa yakni pemuda.

Pencak silat merupakan budaya asli Indonesia yang memiliki empat aspek yaitu: Aspek mental spiritual, aspek seni budaya, aspek beladiri, dan aspek olahraga. Keempat aspek tersebut dalam satu kesatuan yang utuh. Selain empat tersebut pencak silat juga mengandung nilai-nilai positif yaitu : 1) Meningkatkan ketaqwaan kepada Tuhan Yang Maha Esa, 2) Cinta Tanah Air dan Bangsa, 3) Kesehatan dan kebugaran, 4) Membangkitkan rasa percaya diri, 5) Melatih ketahanan mental, 6) Mengembangkan kewaspadaan diri yang tinggi, 7) Membina spotifitas dan jiwa ksatria, 8) Disiplin dan keuletan yang lebih tinggi. Secara keseluruhan pencak silat mengajarkan sifatdan sikap taqwa, tanggap, tangguh, tanggon dan trengginas.
\end{abstract}

Kata Kunci: pencak silat, nilai-nilai luhur, moralitas, bangsa.

\section{PENDAHULUAN}

Pencak silat merupakan seni beladiri tardisional asli bangsa Indonesia. Pencak silat sebagai bagian kebudayaan Indonesia berkembang sejalan dengan sejarah perkembangan masyarakat. Kini seni 
pencak silat mulai berkembang luas dikenal di Indonesia, bahkan mulai berkembang luas ke Negara tetangga yang berbangsa melayu.

Pencak silat berasal dari dua suku kata yaitu pencak dan silat. Pencak berarti gerakan dasar beladiri yang terkait pada peraturan. Silat mempunyai pengertian gerak bela diri yang sempurna yang bersumber pada kerohanian yang suci murni, guna keselamatan diri atau keselamatan bersama, menghindarkan diri/manusia dari bala atau bencana (perampok, penyakit, tenung dan segala sesuatu yang jahat atau merugikan masyarakat). Dalam perkembangnya kin istilah pencak lebih mengedepankan unsur seni dan penampilan gerakan keindahan gerakan, sedangkan silat adalah inti ajaran beladiri dalam pertarungan. Muryono (1999) menyimpulkan bahwa yang menjadi kriteria untuk membedakan arti Pencak dan arti Silat adalah apakah sebuah gerakan itu boleh dipertontonkan atau tidak.

Istilah pencak silat sebagai seni beladiri bangsa Indonesia, merupakan kata majemuk adalah hasil keputusan seminar pencak silat tahun 1973 ditugu Bogor. Pencak silat adalah hasil budaya manusia indonesia untuk membela /mempertahankan aksistensi (kemandirian) dan integritasnya (manunggalnya) terhadap lingkungan hidup guna meningkatkan iman dan taqwa kepada Tuhan Yang Maha Esa( PB IPSI bersama BAKIN, 1975). Kata Pencak maupun Silat sama-sama mengandung pengertian kerohanian, irama, keindahan, kiat, maupun praktek, kenerja, atau aplikasinya.

Notosoejitno (2011) menyatakan bahwa dilihat dari sosok, profil atau tampilan pencak silat di Indonesia ada tiga, yaitu: 
1. Pencak silat asli (original), ialah pencak silat yang berasal dari lokal dan masyarakat etnis di Indonesia.

2. Pencak silat bukan asli yang sebagian besar dari kungfu, karate, dan jujitsu.

3. Pencak silat campuran, ialah campuran antara pencak silat asli dan beladiri asing (beladiri asing yang ingin bergabung dengan nama pencak silat sesuai peraturan).

\section{PEMBAHASAN}

Seiring berkembangnya jaman kini pencak silat telah menjadi budaya Indonesia. Dan menjadi karakteristik masyarakat kita, barang tentu akan menjadi salah astau unsur perekat bangsa untuk bersatu dan mengangkat harkat, derajat, dan martabat bangsa Indonesia dimata dunia.

Berbanding terbalik dengan harapan pencak silat, bangsa Indonesia dewasa ini mengalami berbagai macam krisi baik ekonomo, politik, hokum dan moral. Bila kita cermati secara kritis moral merupakan hal yang paling urgen untuk kita perhatikan. Moral merupakan aset pembangunan bangsa, hari ini sudah mulai kehilangan arah karakter yang sesuai dengan kondisi bangsa. Arya Ginanjar (2008) mengatakan bahwa krisis moral dalam masyarakat antara lain ditandai oleh: 1) hilangnya kejujuran, 2) hilangnya rasa tanggungjawab, 3) tidak mampu berpikir jauh kedepan (visioner), 4) rendahnya disiplin, 5) Krisi kerja sama, 6)Krisis keadilan, dan 7) Krisis kepedulian. Keadaan ini secara otomatis menghilangkan jiwa sportivitas, kejujuran, kepercayaan diri, sikap toleransi antar manusia, serta saliang menghargai juga hilang. Yang artinya 
manusia sudah tidak mampu introspeksi diri, mengakui kesalahan dan tidak dapat bersosialisasi dengan baik terhadap orang lain.

Kenyataan diatas menujukkan bahwa sebagian besar masyarakat Indonesia masih belum memiliki karakter yang menuju moral yang positif. Maka dalam rangka membangun sumber daya manusia Indonesia harus terus ditingkatkan melalui pendidikan, diantaranya melalui bidang olahraga. Karena olahraga dapat berfungsi sarana untuk 1) penyaluran emosi, 2) penguatan identitas, 3) kontrol sosial, 4) sosialisasi, 5) agen perubahan, 6) penyaluran kata hati, 7) mencapai keberhasilan (Wuest and Bucher, 1995). Dengan kata lain kegiatan olahraga dapat membentuk molarilatas bangsa Indonesia dan meningkatkan kualitas hidup yang lebih baik.

\section{Nilai - Nilai Luhur dalam Pencak Silat.}

Nilai luhur dalam pencak silat dikembangkan empat aspek dalam satu kesatuan,yaitu: aspek spiritual, aspek seni gerak, aspek beladiri, dan aspek olahraga. Dalam empat aspek tersebut terdapat makna yang terkadung didalamnya. Adapun makna yang terkandunga adalah pengendalian diri, gerakan seni, dan sportifitas. Dengan pengamalan tersebut maka pemebentukan moralitas bangsa dapat ditingkatkan dengan ikut aktif kegiatan olahraga, khususnya olahraga pencak silat.

1. Aspek Pengembangan Mental Spiritual

Pencak silat membangun dan mengembangkan kepribadian dan karakter mulia seseorang. Para pendekar dan maha guru pencak silat zaman dahulu seringkali harus melewati tahapan semedi, tapa atau aspek kebatinan lain untuk mencapai tingkat tinggi ilmunya (Bila dilihat zaman dahulu). 
Saat ini pengembangan aspek spiritual dalam pencak silat yang harus diajarkan adalah pengembangan aspek mental. Adapun aspek mental sebagai berikut:

a. bertaqwa kepada Tuhan Yang Maha Esa dan berbudi luhur. Yang artinya seorang pesilat berkewajiban melaksanakan segala perintah dan menjahui larangan agama. Selain itu seorang pesilat berbudi luhur dengan menghormati orang tua dan berperilaku sopan santun dalam pergaulan. serta cinta Tanah Air dan Bangsa.

b. percaya diri, tenggang rasa dan disiplin yang artinya seorang pesilat berkewajiban tidak bertindak sewena-wena, suka menolong, berani dan tabah menjalani tantangan hidup, tidak putus asa dan patuh pada norma-norma yang mengatur kehidupan.

c. persaudaraan, pengendalian diri dan tanggung jawab social yang artinya seorang pesilat menjalani kerukunan, gotong royong, keselarasan hidup dalam masyarakat, mampu mengatasi masalah dengan musyawarah, dan menempatkan kepetingan umum diatas kepentingan pribadi dan golongan.

2. Aspek pengembangan seni budaya.

Aspek seni diharapkan seorang pesilat memiliki ketrampilan gerak yang serasi dan menarik. Mengembangkan pencak silat sebagia budaya bangsa Indonesia yang mencerminkan luhur, guna memperkuat kepribadian bangsa, mempertebal rasa nasionalisme dan memperkokoh persatuan. Serta mampu menyaring nilai-nilai budaya asing yang negative dan menyerap nilai yang positif guna perbaharuan dalam proses pembangunan.

3. Aspek pengembangan beladiri. 
Pengembangan aspek beladiri artinya bahwa pesilat harus terampil dalam melakukan gerakan secara efektif dan efisien untuk menjamin kesiapan fisik dan mental, yang dilandasi sikap kesatria, tanggap, dan kemampuan mengendalikan diri. Dan diharapakan seorang pesilat memiliki kewajian untuk: 1) berani menegakkan kujujuran 2) tahan ujian dan godaan dalam menghadapi cobaan, 3) tangguh dan ulut dalam meraih cita-cita dan usaha, 4) tanggap, cermat, cepat dan tepat dalam mengahadapi dan menyelesaikan suatu permasalahan, 5) selalu melaksanakan "Ilmu Padi"tidak sombong dan takabur,6) mengunakan keahlian perkelahiannya hanya dalam keadaan terpak untuk keselamatan diri dan menjaga harga diri.

4. Aspek pengembangan olahraga.

Aspek olahraga diharapkan seorang pesilat mempunyai ketrampilan gerak untuk meningkatkan kesegaran jasmani dan kematangan rohani yang dilandaskan pada hidup sehat. Maka pesilat harus memiliki kesadaran untu: 1) berlatih dan melaksanakan olahraga pencak silat sebagai bagian dari kehidupan sehari-hari, 2) selalu menyempurnakan prestasi jika latihan dan pelaksanaan olahraga tersebut terbentuk pertandingan, 3) menjunjung tinggi spotifitas (M.Atok Iskandar, dkk,1992). Sifat dan sikap ideal tersebut sebagai satu kesatuan dapat diringkas sebagai sifat dan taqwa, tanggap, tangguh, tangon, dan trengginas.

Sifat dan sikap ideal sebagai materi pendidikan yang terkandung dalam empat aspek sebagai satu kesatuan adalah nilai-nilai luhur pencak silat dan merupakan penjabaran Pancasila. Dapat dikatan tujuan yang ingin dicapai dalam pendidikan pencak silat adalah untuk 
membentuk manusia seutuhnya yangberlandasan pada pancasila dan UUD 1945.

\section{Nilai Positif Pencak Silat}

Olahraga pencak silat selain memiliki nilai-nilai luhur, pencak silat juga memiliki nilai positif didalamnya. Berikut adalah beberapa nilai positif yang dipeloleh dalam olahraga beladiri pencak silat yaitu:

1. Meningkatkan ketaqwaan kepada Tuhan Yang Maha Esa

2. Cinta Tanah Air dan Bangsa

3. Kesehatan dan kebugaran

4. Membangkitkan rasa percaya diri

5. Melatih ketahanan mental

6. Mengembangkan kewaspadaan diri yang tinggi

7. Membina spotifitas dan jiwa ksatria

8. Disiplin dan keuletan yang lebih tinggi

Pencak silat memiliki peranan cukup penting dalam meningkatkan sikap, mental dan kualitas generasi muda. Hal ini tentu saja akan terkait dengan tujuan pengembangan generasi muda yang berkesinambungan, sehingga pencak silat menjadi suatu peluang bagi lembaga-lembaga pendidikan untuk ikut membantu meningkatkan kualitas peserta didik melalui pelatihan sikap mental dan kedisiplinan sehingga akan mencetak generasi muda yang berjiwa ksatria.

Sebagai refleksi dari nilai-nilai masyarakat, pencak silat merupakan sebuah sistem budaya yang saling mempengaruhi dengan alam dilingkungannya dan tidak dapat dipisahkan dari aktivitas manusia. Bila pada tingkat perseorangan pencak silat membina agar manusia bias 
menjadi teladan yang mematuhi norma-norma masyarakat, sedangakn pada tingkat kelompok atau aliran pencak silat bersifat kohensif yang dapat merangkul individu-individu dan meningkatkan persaudaran dalam hidup bersosial.

\section{KESIMPULAN}

Pencak silat merupakan salah satu olahraga tradisional bangsa Indonesia yang harus dilestarikan. Pengertian pencak silat memiliki suatu pengertian yang sangat luas dan memiliki fungsi yang jelas, diantaranya adalahbahwa pencak silat sebagai alat untuk beladiri, sebagai wahana spiritual, sebagai pertunjukan atau kesenian, dan sebagai sarana untuk membela bangsa nilai-nilai positif yang terkadung dalam pencak silat, yaitu : 1) Meningkatkan ketaqwaan kepada Tuhan Yang Maha Esa, 2) Cinta Tanah Air dan Bangsa, 3) Kesehatan dan kebugaran, 4) Membangkitkan rasa percaya diri, 5) Melatih ketahanan mental, 6) Mengembangkan kewaspadaan diri yang tinggi, 7) Membina spotifitas dan jiwa ksatria, 8) Disiplin dan keuletan yang lebih tinggi. Secara keseluruhan pencak silat mengajarkan sifatdan sikap taqwa, tanggap, tangguh, tanggon dan trengginas.

\section{DAFTAR PUSTAKA}

Ginanjar, Arya. 2008. Pembentukan Habit Menerapkan Nilai-Nilai Religious, Sosisal, dan Akademik, 29-31 juli 2008. Semiloka Pendidikan Karakter. Yogyakarta; UNY.

M., Saleh. 1991. Pecak Silat (Sejarah Perkembangan, Empat Aspek, Pembentukan Sikap dan gerak). Bandung;IKIP 
Maryono, O'ong. 2000. Pencak Silat: Merentang Waktu. Yogyakarta; Galang

P M. Atok Iskandar, dkk.1992. Pencak Silat. Jakarta; Dirjen Dikti Departemen P dan K.

Subroto, Joko, dan Moh. Rohadi, 1996. Kaidah-Kaidah Pencak Silat Seni Yang Tergabung dalam IPSI. Solo; CV Aneka

Wuest, Deborah A., And Bucher, Charles A. 1995. Foundation of Physical Education and sport, $12^{\text {th }}$ ed.St. Louis, Missouri: Mosby-Year Bool,Inc. 